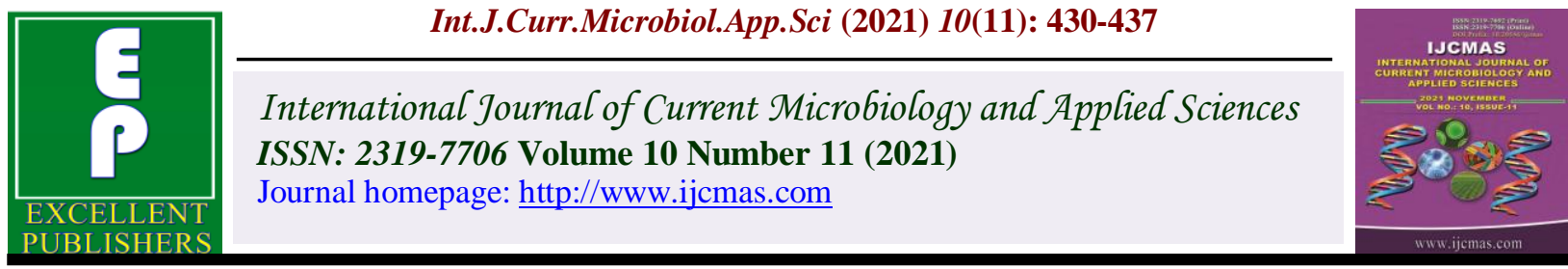

\title{
Evaluation of the Fertilizing and Nematicidal Effects of Lixiviate from Banana Rachis and Purpureocillium lilacinum for a Reduction of Fallow Frequency in Dessert Banana Monoculture
}

\author{
Serge Pacôme Seri ${ }^{1 *}$, Demby Laetitia Muriel Kouadio², \\ Phillipe Gnonhouri ${ }^{2}$ and Louise Turquin ${ }^{1}$
}

\author{
${ }^{1}$ Laboratory of Biotechnology, Agriculture and Valorization of Biological Resources, \\ University Félix HOUPHOUET-BOIGNY (UFHB), UFR Biosciences, 22 BP 582 \\ Abidjan 22, Côte d'Ivoire. \\ ${ }^{2}$ Laboratory of Nematology, National Center of Agronomic Research, 01 BP 1536 \\ Abidjan 01, Côte d'Ivoire. \\ *Corresponding author
}

\section{Keywords}

Radopholus similis, Pratylenchus coffeae, fallow land, banana plantain lixiviate

Article Info

Received: 05 October 2021 Accepted: 07 November 2021 Available Online: 10 November 2021

\section{A B S T R A C T}

The practice of fallowing for one year represents a viable alternative to chemical control of Radopholus similis and Pratylenchus coffeae in dessert banana monoculture. Although necessary, fallowing has an economic disadvantage for farmers. The objective of this work is to evaluate the nematicidal and fertilizing effects of lixiviate from banana rachis and Purpureocillium lilacinum in order to reduce the frequency of fallowing. In this study, we performed a chemical analysis of the lixiviate and then compared the two types (plantain lixiviate and dessert lixiviate) at $25 \%$ concentration, Bioact (Purpureocillium lilacinum) at $10^{6}$ spores $/ \mathrm{ml}$ ) and two mixed treatments (plantain lixiviate + Bioact and dessert lixiviate + Bioact) to an untreated control and a reference nematicide, fluopyram at 10\% (Verango) during three cycles of cultivation of the dessert banana seedling Grande naine. At the end of each crop cycle, the evolution of the nematode population and the yield of banana plants were evaluated. Chemical analysis revealed a high potassium content in both products and a more remarkable amount of nitrogen in the plantain lixiviate. The results showed that Bioact did not show antagonistic effect against nematodes and impact on production. On the other hand, despite less nematicidal activity, the lixiviate significantly increased the yield compared to the chemical nematicide treatment. Therefore, only in the plots treated with lixiviate, it was possible to carry out several successive crop cycles. This result was more marked with the plantain lixiviate. The results presented in this work are encouraging for the development of biological control methods of banana nematodes by lixiviate. 


\section{Introduction}

Among the production constraints, endoparasitic nematodes (Radopholus similis and Pratylenchus coffeae) constitute one of the major limiting factors to banana production, causing extensive root damage, resulting in serious economic losses (Queneherve, 2009). According to the "resource concentration hypothesis" (Root 1973), monocultures are more prone to diseases and pest infestations. In the case of banana monocultures, the soils have large populations of Radopholus similis and Pratylenchus coffeae and a problem of fertility degradation after a few cropping cycles (Risède et al., 2018; Pattison et al., 2011; Gnonhouri and Adiko 2008). This situation forces farmers to turn to prophylactic methods such as fallowing for at least one year to allow the soil to regenerate while eliminating fooddeprived nematodes (Tabarant et al., 2011). However, the regular integration of the fallow phase into the farmer's calendar is a practice that does not always lead to economic benefits for most farms: production targets are set and replanted in vitro plants are expensive. For the small producer, the practice of fallowing is inconvenient because it requires sufficient acreage to be able to deprive himself of a part of his farm (Chabrier, 2005). These different constraints make it a priority to find solutions that will prevent the development of nematodes and promote long-term soil enrichment. The use of organic matter leads to a series of biological processes related to its degradation, which can reduce plant-parasitic nematode populations and restore the soil's organic matter stock and humus (Oka, 2010). Lixiviate, a liquid organic compound, is extracted from plantain and banana rachis. This product has demonstrated fertilizing efficacy in tomato crops and nematicidal efficacy under in vivo conditions (Muñoz, 2005; Seri et al., 2018). Another strategy for the sustainable management of nematodes and improving soil fertility is through the use of biological control agents such as nematophagous fungi (Hernández-Leal et al., 2016).Among nematophagous fungi, Purpureocillium lilacinum (former name var Paecilomycès lilacinum) is of increasing interest by virtue of its ability to parasitize nematodes and improve soil fertility (Messa, 2020). The objective of the present study is to evaluate the nematicidal and fertilizing effects of lixiviate from banana rachis and Purpureocillium lilacinum in a context of reduced fallow frequency in dessert banana cv Grande naine plantations.

\section{Materials and Methods}

\section{Plant material}

The plant material consisted of dessert banana cv Grande naine in vitro plants. The lixiviate was obtained from plantain cv Corne 1, and dessert banana cv Grande naine rachis.

\section{Fungal material}

Purpureocillium lilacinum, trade name Bioact DC, was supplied to us by the firm Bayer Crop Science.

\section{Lixiviate preparation}

The preparation of the lixiviate from plantain (lixp) and banana dessert (lixd) rachis was done using an anaerobic composting process. The slightly modified INRA, (2014) method was used for lixiviate preparation. The rachis were fragmented ( $3 \mathrm{~cm}$ thick and $10 \mathrm{~cm}$ long). Eight kilograms of cut rachis were mixed with 151 of distilled water in a 201 drum, then hermetically sealed and stored at $27^{\circ} \mathrm{C}$ at the Nematology Laboratory of the CNRA or National Agricultural Research Center. The mixture was stirred manually and vigorously each day for $2 \mathrm{~min}$. After three months of maceration, the resulting solution was filtered 
through a sieve (250 $\mu$ mesh diameter) to obtain the lixiviate.

\section{Mineral composition and chemical properties of lixiviate}

The constituents were quantified by various methods:

total nitrogen was determined by the Kjeldhal method (Goyal et al., 2005);

potassium (K) and calcium (Ca) were determined by flame spectrophotometry after incineration and mineralization with hydrochloric acid;

phosphoric acid was determined by the colorimetric method on the hydrochloric solution of solution of the ashes thanks to the yellow coloration that it gives with the vanadomolybdic reagent;

$\mathrm{pH}$ of the lixiviate was measured with a $\mathrm{pH}$ meter.

\section{Experimental device}

The trial was conducted on a SAKJ plot, ready to be fallowed, which had a high inoculum (21000 endoparasitic nematodes/100 g root) and a low productivity (15 t/ha). The trial started three months after planting the in vitro plants and was conducted over three growing cycles. The preliminary nematological analysis allowed to verify the homogeneity of the initial infestation within the plot (6000 endoparasitic nematodes/100 $\mathrm{g}$ of roots).

Both types of lixiviate (plantain lixp and dessert lixd) at the $25 \%$ concentration, Bioact $\mathrm{DC}$ at $10^{6}$ spores $/ \mathrm{ml}$ and two mixed treatments [plantain lixiviate (lixp) + Bioact and banana dessert lixiviate (lixd) + Bioact) were compared to an untreated control and a reference nematicide, Fluopyram at $10 \%$
(Verango). Lixiviate treatments were applied monthly until the end of the trial at 500 $\mathrm{ml} /$ plant. Bioact was applied every two months for six months at $82 \mathrm{ml} /$ plant. For the mixed treatments (lixiviate + Bioact), the two products were applied alternately every month for six months and subsequent applications were only to lixiviate every month until the end of the trial. Fluopyram was applied once every four months at an amount of 50 $\mathrm{ml} /$ plant. The device chosen was a complete randomized block with five replications. Each plot was $275 \mathrm{~m}^{2}(11 \mathrm{~m} \times 25 \mathrm{~m})$ and consisted of 48 plants, 24 of which were studied, surrounded by a belt of 24 border plants.

\section{Nematological analysis}

The nematode population was assessed at flowering of each crop cycle after extraction of nematodes by the double centrifugation technique (Coolen and d'Herde, 1972). Nematode numbers were expressed as the number of nematodes per $100 \mathrm{~g}$ of roots.

\section{Evaluation of vegetative and production parameters}

The vegetative parameters that were measured at flowering of each crop cycle were the height $(\mathrm{H})$ and circumference $(\mathrm{C})$ of banana plants. They are expressed in $\mathrm{cm}$.

The following production parameters were evaluated: planting-flowering interval (IPF), flowering-harvest interval (IFR), number of hands $(\mathrm{Nm})$, bunch mass $(\mathrm{M})$ and proportion of bunch harvested (Pr). The gross yield $(\mathrm{Rb})$ of each cycle was calculated according to the following formula:

$\mathrm{Rb}=(\mathrm{Mm} \cdot \mathrm{PR} \cdot \mathrm{D} \cdot 365) / \mathrm{Cy}$

Mm: average mass of a bunch, Pr: proportion of bunches harvested, D: density of plants (plants/ha) and Cy: cycle length in days. 


\section{Statistical analysis}

ANOVAs were performed to compare the means of the variables by treatment. In case of significant difference at the 5\% level, Fisher's LSD test was used to compare the means. Nonparametric tests were also performed to test the significance $(\mathrm{P}<0.05)$ of some means per treatment. Nematode populations were transformed to $\log 10(x+1)$ decimal and percentages were transformed using the $\operatorname{arcsine}(\mathrm{x} / 100)$ before statistical analysis.

\section{Results and Discussion}

Mineral content and chemical properties of lixiviate

Analysis of the content of mineral constituents [nitrogen $(\mathrm{N})$, phosphorus $(\mathrm{P})$, potassium $(\mathrm{K})$, calcium $(\mathrm{Ca})]$ of the different lixiviate shows a significant difference for the average values of nitrogen and calcium (Table 1). The plantain lixiviate is richer in nitrogen (0.9 vs. 0.3). For calcium, the dessert lixiviate has the highest content (41 vs. 17). The $\mathrm{pH}$ values of the two lixiviate are statistically close.
Effects of lixiviate and Bioact on Radopholus similis and Pratylenchus coffeae

Population results of $R$. similis and $P$. coffeae nematodes at flowering for the three crop cycles are recorded in Table 2.In the control and Bioact treated plots, the development of infestations was statistically similar over the three cycles. At flowering of the first cycle, the population level was around 14000 nematodes/100 $\mathrm{g}$ of roots. Infestations increased steadily with the favorable rainfall conditions at flowering of the 2nd and 3rd cycle (20000 nematodes $/ 100 \mathrm{~g}$ of roots). This result shows that Bioact did not have a nematicidal effect. At all lixiviate plots (lixp, lixd, lixp + Bioact and lixd + Bioact), nematode population densities were statistically similar. The level of infestation (6000 nematodes $/ 100 \mathrm{~g}$ roots) was significantly lower in the control and Bioact plots but higher than in the plots that received the chemical treatment (2200 nematodes/100 g roots). These results show a more effective nematicidal action of fluopyram compared to lixiviate.

Table.1 Mineral content (N, P, K, Ca) and $\mathrm{pH}$ of the lixiviate

\begin{tabular}{|c|c|c|c|c|c|}
\hline Lixiviate & Nt \% & P & K & Ca & pH \\
\hline Plantain & 0,9 a & 1,6 & 471 & 17 b & 7,4 \\
\hline Dessert & $0,3 \mathrm{~b}$ & 1,5 & 475 & $41 \mathrm{a}$ & 7,1 \\
\hline
\end{tabular}

In the same column, the averages affected with different letters indicate significant differences between treatments according to Student $\mathrm{T}$ test $(\mathrm{P}=0,05)$.

Table.2 Population of endoparasitic nematodes at flowering in each cycle

\begin{tabular}{|c|c|c|c|c|c|c|c|c|}
\hline \multicolumn{7}{|c|}{ Treatments } \\
\hline Cycles & Control & Fluopyram & Bioact & Lixp & Lixd & $\begin{array}{l}\text { Lixp + } \\
\text { Bioact }\end{array}$ & $\begin{array}{l}\text { Lixd + } \\
\text { Bioact }\end{array}$ & Meaning \\
\hline Cycle 1 & $13349 \mathrm{a}$ & $2123 \mathrm{c}$ & $14920 \mathrm{a}$ & $5575 \mathrm{~b}$ & $6111 \mathrm{~b}$ & $5573 \mathrm{~b}$ & $5518 \mathrm{~b}$ & S \\
\hline Cycle 2 & $20471 \mathrm{a}$ & $1837 \mathrm{c}$ & $18766 \mathrm{a}$ & $5668 \mathrm{~b}$ & $7221 \mathrm{~b}$ & $5094 \mathrm{~b}$ & $6359 \mathrm{~b}$ & S \\
\hline Cycle 3 & $22076 \mathrm{a}$ & $2668 \mathrm{c}$ & $19023 \mathrm{a}$ & $6271 \mathrm{~b}$ & $5394 \mathrm{~b}$ & $6165 \mathrm{~b}$ & $6010 \mathrm{~b}$ & S \\
\hline Moyenne & $17965 \mathrm{a}$ & $2209 \mathrm{c}$ & $17570 \mathrm{a}$ & $5838 \mathrm{~b}$ & $6242 \mathrm{~b}$ & $5610 \mathrm{~b}$ & $5963 \mathrm{~b}$ & S \\
\hline
\end{tabular}

In the same row, the averages affected with different letters indicate significant differences between treatments $(\mathrm{P}=0,05)$

Plantain lixiviate : lixp ; lixiviate dessert: lixd. Data are averages of fIve replicates 
Table.3 Vegetative and production parameters at flowering of each cycle

\begin{tabular}{|c|c|c|c|c|c|c|c|c|c|}
\hline \multirow[b]{2}{*}{ Cycles } & \multirow[b]{2}{*}{ Parameters } & \multicolumn{7}{|c|}{ Treatments } & \\
\hline & & Control & Fluopyram & Bioact & Lixp & Lixd & Lixp + Bioact & Lixd + Bioact & \\
\hline \multirow[t]{8}{*}{1} & H (cm) & $206,8 \pm b$ & $223,8 \mathrm{a}$ & $207,9 \mathrm{~b}$ & $227,4 \mathrm{a}$ & $222,7 \mathrm{a}$ & $228,2 \mathrm{a}$ & $225,5 \mathrm{a}$ & $\mathrm{S}$ \\
\hline & $\mathrm{C}(\mathrm{cm})$ & $41,8 \mathrm{~b}$ & $47,5 \mathrm{a}$ & $42,3 \mathrm{~b}$ & $48,1 \mathrm{a}$ & $47,6 \mathrm{a}$ & $48,1 \mathrm{a}$ & 47,6 a & $\mathrm{S}$ \\
\hline & IPF $1(\mathbf{j})$ & $226,5 \mathrm{~b}$ & $218,3 \mathrm{a}$ & $225,2 \mathrm{~b}$ & $215,5 \mathrm{a}$ & $218,1 \mathrm{~b}$ & $214,5 \mathrm{~b}$ & $216,8 \mathrm{~b}$ & $\mathrm{~S}$ \\
\hline & IP1R1 (j) & $316,5 b$ & $308,3 \mathrm{a}$ & $315,2 \mathrm{~b}$ & $305,5 \mathrm{a}$ & $308,1 \mathrm{a}$ & $304,5 \mathrm{a}$ & $306,8 \mathrm{a}$ & $\mathrm{S}$ \\
\hline & $\mathrm{Nm}$ & 8,3 & 8,4 & 8,3 & 8,5 & 8,5 & 8,5 & 8,5 & NS \\
\hline & M (Kg) & $17,4 \mathrm{~b}$ & $19,8 \mathrm{a}$ & $17,5 \mathrm{~b}$ & $21,2 \mathrm{a}$ & $21 \mathrm{a}$ & $21,4 \mathrm{a}$ & $21,2 \mathrm{a}$ & $\mathrm{S}$ \\
\hline & $\operatorname{Pr}(\%)$ & $60 c$ & $91,4 \mathrm{a}$ & $63 c$ & $86 \mathrm{~b}$ & $86 \mathrm{~b}$ & $86 \mathrm{~b}$ & $86 \mathrm{~b}$ & $\mathrm{~S}$ \\
\hline & $\mathbf{R b}(\mathbf{t})$ & $20,50 \mathrm{~b}$ & $36,40 \mathrm{a}$ & $21,70 \mathrm{~b}$ & $37,00 \mathrm{a}$ & $36,40 \mathrm{a}$ & $37,50 \mathrm{a}$ & $36,90 \mathrm{a}$ & $\mathrm{S}$ \\
\hline \multirow[t]{8}{*}{2} & H (cm) & $218,5 \mathrm{~b}$ & $233,1 \mathrm{ab}$ & $214,3 \mathrm{~b}$ & $257,1 \mathrm{a}$ & $254,9 \mathrm{a}$ & $259,7 \mathrm{a}$ & $255,6 \mathrm{a}$ & $\mathrm{S}$ \\
\hline & $\mathrm{C}(\mathrm{cm})$ & $44,1 \mathrm{c}$ & $50,2 \mathrm{~b}$ & $45,2 \mathrm{c}$ & $62,3 \mathrm{a}$ & $61,6 \mathrm{a}$ & $62,7 \mathrm{a}$ & $62 \mathrm{a}$ & $\mathrm{S}$ \\
\hline & IR1F2 (j) & $116,2 \mathrm{~b}$ & $107,4 \mathrm{ab}$ & $114,3 \mathrm{~b}$ & $100,7 \mathrm{a}$ & $101,6 \mathrm{a}$ & $100,4 \mathrm{a}$ & $101,8 \mathrm{a}$ & $\mathrm{S}$ \\
\hline & $\operatorname{IR1R2}(\mathbf{j})$ & $206,2 \mathrm{~b}$ & $197,4 \mathrm{~b}$ & $204,2 \mathrm{~b}$ & $186,3 \mathrm{a}$ & $187,6 \mathrm{a}$ & $185,6 \mathrm{a}$ & $186,8 \mathrm{a}$ & $\mathrm{S}$ \\
\hline & $\mathbf{N m}$ & 8,1 & 8,4 & 8,1 & 8,8 & 8,6 & 8,8 & 8,8 & NS \\
\hline & $\mathbf{M}(\mathbf{K g})$ & $15,04 \mathrm{c}$ & $18,1 \mathrm{~b}$ & $15,6 \mathrm{c}$ & $22,5 \mathrm{a}$ & $22,1 \mathrm{a}$ & 22,9 a & $22,6 \mathrm{a}$ & $\mathrm{S}$ \\
\hline & $\operatorname{Pr}(\%)$ & $63 c$ & 88,6 a & $63 c$ & $83 \mathrm{~b}$ & $83 \mathrm{~b}$ & $83 \mathrm{~b}$ & $83 \mathrm{~b}$ & $\mathrm{~S}$ \\
\hline & $\mathbf{R b}(\mathbf{t})$ & $28,5 \mathrm{c}$ & $50,4 \mathrm{~b}$ & $29,8 \mathrm{c}$ & $62,2 \mathrm{a}$ & $60,6 \mathrm{a}$ & $63,5 \mathrm{a}$ & $62,3 \mathrm{a}$ & $\mathrm{S}$ \\
\hline \multirow[t]{8}{*}{3} & H (cm) & $257,4 \mathrm{c}$ & $303,6 \mathrm{~b}$ & $261,4 \mathrm{c}$ & $322,2 \mathrm{a}$ & $319 a$ & $323,1 \mathrm{a}$ & $322 \mathrm{a}$ & $\mathrm{S}$ \\
\hline & $\mathrm{C}(\mathrm{cm})$ & $43,9 \mathrm{c}$ & $50 \mathrm{~b}$ & $44,8 \mathrm{c}$ & $64,8 \mathrm{a}$ & $63,6 \mathrm{a}$ & $65,7 \mathrm{a}$ & $63,8 \mathrm{a}$ & $\mathrm{S}$ \\
\hline & IR2F3 (j) & $187,3 \mathrm{~b}$ & $185 \mathrm{~b}$ & $184,3 \mathrm{~b}$ & 166,9 a & $168,3 \mathrm{a}$ & $164,4 \mathrm{a}$ & $167,7 \mathrm{a}$ & $\mathrm{S}$ \\
\hline & IR2R3 (j) & $277,3 \mathrm{~b}$ & $275 \mathrm{~b}$ & $274,3 \mathrm{~b}$ & $250,9 \mathrm{a}$ & $253,3 \mathrm{a}$ & $249,4 \mathrm{a}$ & $252,7 \mathrm{a}$ & S \\
\hline & $\mathbf{N m}$ & $7,9 \mathrm{~b}$ & $8 \mathrm{~b}$ & $8 \mathrm{~b}$ & $9,6 \mathrm{a}$ & $9,4 \mathrm{a}$ & $9,7 \mathrm{a}$ & $9,6 \mathrm{a}$ & $\mathrm{S}$ \\
\hline & M (Kg) & $14,1 \mathrm{c}$ & $17,1 \mathrm{~b}$ & $14,6 \mathrm{c}$ & $24,6 \mathrm{ab}$ & $22,2 \mathrm{~b}$ & $26,9 \mathrm{a}$ & $24,9 \mathrm{ab}$ & $\mathrm{S}$ \\
\hline & $\operatorname{Pr}(\%)$ & $43 \mathrm{~d}$ & $86 \mathrm{a}$ & $48 \mathrm{c}$ & $83 \mathrm{~b}$ & $83 \mathrm{~b}$ & $83 \mathrm{~b}$ & $83 \mathrm{~b}$ & $\mathrm{~S}$ \\
\hline & $\mathbf{R b}(\mathbf{t})$ & $13,6 \mathrm{~d}$ & $33,2 \mathrm{c}$ & $15,8 \mathrm{~d}$ & $50,5 \mathrm{ab}$ & $45,1 \mathrm{~b}$ & 55,5 a & $50,7 \mathrm{ab}$ & $\mathrm{S}$ \\
\hline
\end{tabular}

H: height; C: circumference; IPF1: planting-flowering interval 1; IPR1: planting-harvest interval 1;

IR1F2: harvest 1-flowering 2 interval; IR1R2: harvest 1-harvest 2 interval; IR2F3: harvest 2-flowering 3 interval; IR2R3: harvest 2-harvest 3 interval; Nm: number of hands; M: mass; Pr: percentage of bunch harvested;

$\mathrm{Rb}$ : gross annual yield; S: significant; NS: not significant. Data are averages of five replicates 
Influence of lixiviate and Bioact on vegetative parameters and production

Plant growth and productivity in the control and Bioact-treated plots were significantly lower than in the other treatments during all three growing cycles and flowering was late. Many plants fell (approximately 37\% in the first and second cycles and approximately $45 \%$ of plant harvested in the third cycle) between flowering and harvest, and the average mass of harvested bunches was low, resulting in low yields. In the third cycle, the yield was three times lower, for the control (13.6 t) and Bioact $(15.8 \mathrm{t})$ against approximately $50 \mathrm{t}$ for the lixiviate treatments. The chemical nematicide treatment of the plots resulted in an increase in the number of harvested plants (approximately $90 \%$ ), however their productivity was significantly lower than that of the lixiviatetreated plots. Indeed, the application of lixiviate resulted in an early flowering and an increase in the mass of harvested bunches.

The present study results show an improvement in production in the presence of lixiviate. Of all the lixiviate treatments, productivity was better in the plantain lixiviate plots especially when combined with Bioact. This result shows a more pronounced fertilizing activity of the plantain lixiviate.

The low yields observed over the three cycles in the control and Bioact plots can be explained by the high parasite pressure in these plots. Indeed, the growth and yield of a banana plant depend on the health of its roots (Sen, 2005). Our results corroborate those of Mukasa et al., (2006), who observed a 40\% decrease in above-ground biomass and yield on banana after nematode attack. Chemical treatment provided better nematicide treatment compared to lixiviate treatment, however yield was significantly better for lixiviate treatments. This result suggests a tolerance mechanism in the plots that received the lixiviate.Nutrients in quality and quantity in the lixiviate, especially potassium and nitrogen, compensated for the damage inflicted on the plant by nematodes by improving soil fertility.Such effects of organic matter were observed with McIntyre et al., (2000).In addition, other studies have shown that the input of lixiviate to the soil positively influenced microbial activity (Muñoz, 2005; Bautista et al., 2015) including endomycorrhizae which are potential agents of plant tolerance to nematodes (Elsen et al., 2003).The more pronounced fertilizing activity of plantain lixiviate could be explained by its higher nitrogen content. This observation was also highlighted in the work of Herrera (2018) who advocates the use of plantain lixiviate for better fertilization. Based on the production criteria (level of productivity and nematode inoculum present) in the 3rd cycle, increasing the number of production cycles was only feasible for the lixiviate treated plots. Fallowing of the control and Bioact plots was imminent due to the low production level and high nematode inoculum. The same was true for the Fluopyram-treated plots, where the cost of repeated application was becoming prohibitive for such declining productivity.

In the present study, plantain and dessert lixiviate showed fertilizing and nematicidal effects. These properties were more optimized with the plantain lixiviate especially when combined with Bioact. Bioact alone had no effect on the evolution of the nematode population, but seemed to improve soil enrichment. In a context of reduced fallow frequency, the application of lixiviate preferentially from plantain could contribute to increasing the number of crop cycles in intensive dessert banana cv Gandenaine monoculture.

\section{References}

Bautista L G, Bolaños M M, Asakawa N M, Villegas B, 2015. Respuesta de 
fitonematodos de plátanoMusa $\mathrm{AAB}$ Simmonds a estrategias de manejointegradodelsuelo y nutrición. Revista Luna Azul, 40: 1909-2474.

Chabrier C, 2005. Essai de l'efficacité et de la sélectivité du BioAct ${ }^{\circledR}$ WG (Paecilomyces lilacinus, souche 251) vis-à-vis des nématodes du bananier à la Martinique. Montpellier: CIRADFLHOR, 18 p.

Coolen, W. A. and C. J. D'Herde1972. A method for the quantitative extraction of nematodes from plant tissue. State Agricultural Research Center, Ghent, Belgium, 77 pp.

Elsen A, Baimey H, Sweenen R, De Waele D, 2003. Relative mycorrhizal dependency and mycorrhiza-nematode interaction in banana cultivars (Musa spp.) differing in nematode susceptibility. Plant and Soil256, 303313.

Gnonhouri P, Adiko A, 2008. Distribution géographique de Radopholus similis et Pratylenchus coffeae. Risque potentiel sur la pérennisation des plantations de bananiers dessert en Côte d'ivoire. AgronomieAfricaine, 20 (2) : 213- 220.

Goyal S, Dhull, S K et Kapoor K K, 2005. Chemical and biological changes during composting of different organic wastes and assessment of compost maturity. Bioresourcetechnology, 96 (14) : 1584-1591.

Hernández-Leal T, López-Lima D, Carrión G, 2016. Effect of the application of nematophagous fungus Purpureocillium lilacinum over nutrients availability on agricultural soil and yield of Avena sativa. Revista de la Facultad de CienciasAgrarias, $48: 1-12$.

Herrera H G, 2018.Comparación de la calidad y effectos de lixiviadosobtenidosa partir de raquisde banano (Musa acuminata) y platano (Musa

\section{balbisiana)}

mediantetransformaciónaerobica y anaerobica en conditiones de invernadero. Tesis de la Facultad de Ingeniería en Mecánica y Ciencias de la Producción, Guayaquil - Ecuador 124 p.

INRA 2014. Lixiviate production: how to proceed? Tropical Agro Systems Research Unit. National Institute of Agronomic Research (INRA, AntillesGuyane). Banana Plantain Seminar Report, $2 \mathrm{p}$

J-M Risède, R Achard, P Brat, C Chabrier, G Damour, C Guillermet, L de Lapeyre, D Loeillet, S Lakhia, P Meynard, P Tixier, H T Quoc, F Salmon, F-X Côte, M Dorel, 2019. La transition agro-écologique des systèmes de culture de bananes Cavendish aux Antilles françaises, In :"La transition agro-écologique des agricultures $d u$ Sud",janvier 2019, Editeur : EditionQuae, 368p.

McIntyre B D, Speijer P R, Riha S J, Kizito F, 2000. Effects of mulching on biomass, nutrients, and soil water in banana inoculated with nematodes. Agronomy Journal 92, 1081-1085.

Messa, V, R (2020). Controlebiológico de fitonematóidesmedianteaplicação de fungosnematófago emicorrízi cosnacultura da soja. Dissertação (Mestradoem Fitopatologia), Universi dadeEstadual do oeste do paraná.

Mukasa H H, David O, De Waele D, Rubaihayo P R, Blomme G, 2006. Effect of a multispecies nematode population on the root, corm, and shoot growth of East African Musa genotypes. Biology and Fertility of Soils, 43 : 229-235.

Muñoz R E, 2005. Efecto de lixiviadosdelraquis de plátano sobre la actividad y biomasamicrobiana en floración y cosechadel tomateP.h.D, 
UniversidadNacional de Colombia : $237 \mathrm{p}$.

Oka Y, 2010. Mechanisms of nematode suppression by organic soil amendments. Applied Soil Ecology, 44:101-115.

Pattison A B, Badcock K, Sikora R A, 2011. Influence of soil organic amendments on suppression of the burrowing nematode, Radopholus similis, on the growth of bananas. Australas Plant Path40: 385-396.

Queneherve P (2009). Integrated management of banana nematodes. In: Ciancio A, Mukerji K G (eds) Integrated management of fruit crops and forest nematodes. Springer, Netherlands, pp 3-61

Root R B, 1973. Organization of a plantarthropod association in simple and diverse habitats fauna of collards (Brassica oleracea). Ecological Monographs43: 95-120.

Sen R, 2005. Towards a multifunctional rhizosphere concept: back to the future? New Phytol.168: 266-268.

Seri S. Pacôme, GnonhouriPhillipe, Assiri K. Patrice, Louise Turquin, Hortense A. Diallo Bio-control of the lesion nematode pratylenchus coffeae using lixiviate from banana rachis (sp.).

Internationnal Journal of Phytopathology, (03).129

Tabarant P, Villenave C, Risede J M, RogerEstrade, J, Thuries, L, Dorel M, 2011. Effects of four organic amendments on banana parasitic nematodes and soil nematode communities. AppliedSoilEcology49: 59-67.

\section{How to cite this article:}

Serge Pacôme Seri, Demby Laetitia Muriel Kouadio, Phillipe Gnonhouri and Louise Turquin. 2021. Evaluation of the Fertilizing and Nematicidal Effects of Lixiviate from Banana Rachis and Purpureocillium lilacinum for a Reduction of Fallow Frequency in Dessert Banana Monoculture. Int.J.Curr.Microbiol.App.Sci. 10(11): 430-437. doi: https://doi.org/10.20546/ijcmas.2021.1011.048 